\title{
Compression neuropathy of the median nerve during tissue expansion of the forearm
}

\author{
Chenicheri Balakrishnan MD, Jason L Mussman BA, Shawn Vandemark MD, Venkata S Erella MD
}

C Balakrishnan, JL Mussman, S Vandemark, VS Erella. Compression neuropathy of the median nerve during tissue expansion of the forearm. Can J Plast Surg 2005;13(4):203-204.

Acute median nerve compression usually occurs from increased pressure within the compartments. During tissue expansion of the forearm, the interstitial pressure increases, which usually decreases following the relaxation of tissue. Clinical diagnosis of acute neuropathy is usually made from the history and clinical signs and symptoms. The cases of two patients who developed acute symptoms of neuropathy during tissue expansion of the forearm are presented.

Key Words: Acute compression neuropathy; Tissue expansion

\section{Une neuropathie de compression du nerf médian pendant l'expansion tissulaire de l'avant-bras}

La compression aiguë du nerf médian se produit généralement à cause d'une pression accrue dans les loges. Pendant l'expansion tissulaire de l'avant-bras, la pression interstitielle augmente, mais diminue habituellement après le relâchement des tissus. D'habitude, le diagnostic clinique de neuropathie aiguë est posé après l'anamnèse et l'examen des signes et symptômes cliniques. Le cas de deux patients qui ont présenté des symptômes aigus de neuropathie pendant une expansion tissulaire de l'avantbras est présenté.
C

Tompression of the median nerve at the wrist is the most Althonly recognized nerve entrapment syndrome. various etiologies have been reported for this syndrome, acute compression neuropathy is rare. Tissue expansion has been used to provide local tissue, of similar quality, for closure of soft tissue defect, without the need for skin grafting of the donor site. We report two patients who, during their tissue expansion of the forearm, developed acute symptoms of compression neuropathy.

\section{CASE PRESENTATION}

During a five-year period, two patients were treated for acute median nerve neuropathy following tissue expansion for the excision of burn scars. The etiology of the scarring was contact burns and flame burns, respectively. Tissue expanders were placed in the mid forearm and the expansion started after two weeks. The planned expansion was once a week, which proceeded without any problems during the first four weeks (Figures 1 and 2). Both patients presented with a sudden onset of severe pain in the fingers, which worsened over a few hours following tissue expansion. The pain was severe on extension of the fingers and there was paraesthesia of the median nerve distribution. Tinel's test was positive. A clinical diagnosis of acute median nerve compression was made from clinical signs. Both patients underwent aspiration of fluid from the tissue expander, which relieved the symptoms. Both patients went on to complete the expansion and removal of the scar from the forearm. There

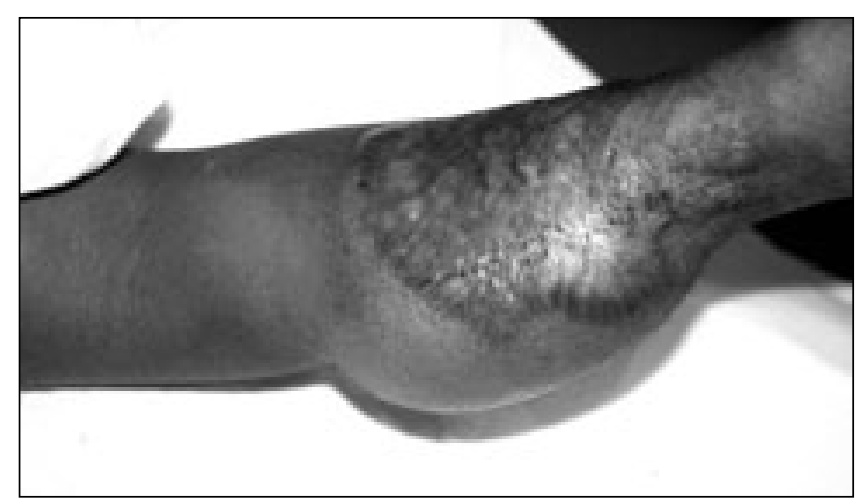

Figure 1) Tissue expander inserted for excision of burn scar

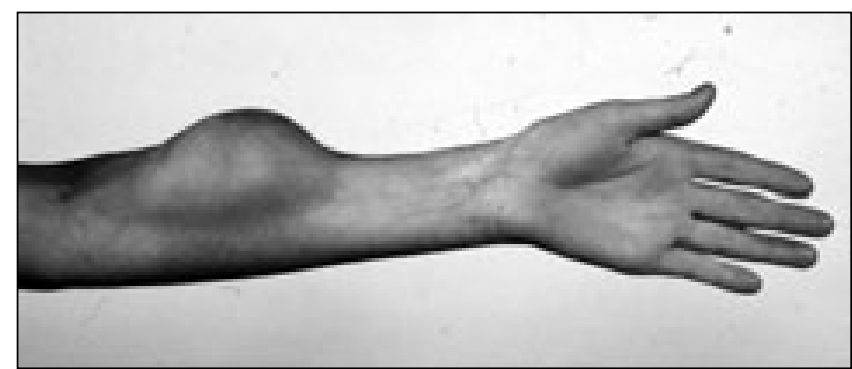

Figure 2) Tissue expander inserted over the flexor aspect of the forearm for excision of burn scar of the dorsal forearm 
were no residual symptoms, and follow-up nerve conduction studies were within normal limits in both patients.

\section{DISCUSSION}

There is a general agreement that raised compartment pressure, above and beyond certain levels for a period of time, leads to vascular compromise of the structures within the compartment. The arterioles close before larger vessels within the compartment and lead to hypoxia of the tissue. Thus, an oxygen-nutrient cutoff theory has been suggested as the pathophysiology of compartment syndrome (1). When intra-compartmental pressure rises above a critical threshold pressure, capillary blood flow is reduced below the level required for median nerve viability. This can occur from bleeding, a foreign body in the compartment, or thrombosis of the median artery or epineural vessels (2-5). Although several conditions are associated with compression neuropathy of the median nerve, acute carpal tunnel syndrome is the most common neuropathy of the median nerve. Because capillary blood flow is reduced below the level required for median nerve viability, this condition warrants prompt recognition and treatment. Although a skin stretching device has primarily been used to close the radial forearm donor site (6), no clinical symptoms of increased compartment pressure have been reported.

In tissue expansion, the observation that living tissues respond in dynamic fashion to mechanical forces placed upon them has been applied to surgical defects. This technique has allowed the surgeon to replace lost or surgically excised tissue with neighbouring tissues of similar colour, texture, sensation and thickness, with little donor site morbidity. Complications associated with soft tissue expansion have been reported with varying incidence, which typically delay reconstruction but do not result in loss of tissue (7). Major complications of tissue expansion resulting in removal or replacement of tissue expander include infection, implant exposure, hematoma and extrusion. Minor complications reported include cellulitis, pain, seroma and widened scars. Antonyshyn et al (8) reported complications necessitating some revision in the original treatment plan in $39 \%$ of patients, without compromising the final result. Because major complications requiring the removal of tissue expander was as high as $38 \%$, careful outpatient observation and constant follow-up has been recommended by some authors (9).

\section{CONCLUSION}

Sudden onset of numbness in the median nerve distribution and pain in the fingers following tissue expansion were the main symptoms in these patients. Although these patients had discomfort following tissue expansion in the past, these symptoms worsened rather than relieved over time. Both patients called and returned to the office within $2 \mathrm{~h}$ to $3 \mathrm{~h}$ of expansion. Removal of approximately $10 \mathrm{~mL}$ of fluid resulted in a full recovery.

\section{REFERENCES}

1. Kumar P. Compartment syndrome: Pathophysiology. Burns 2005;31:120.

2. Bonatz E, Seabol KE. Acute carpal tunnel syndrome in a patient taking coumadin: Case report. J Trauma 1993;35:143-4.

3. Balakrishnan C, Smith MF, Puri P. Acute carpal tunnel syndrome from thrombosed persistent median artery. J Emerg Med 1999;17:437-9.

4. Balakrishnan C, Bradt LM, Sylora RL, Graff N. Acute carpal tunnel syndrome from a foreign body in the carpal tunnel. Can J Plast Surg 2001;10:42-3.

5. Fricker R, Fuhr P, Pippert H, Troeger H. Acute median nerve compression at the distal forearm caused by a thrombosed aneurysm of an epineural vessel: Case report. Neurosurgery 1996;38:194-6.

6. Samis AJ, Davidson JS. Skin-stretching device for intraoperative primary closure of radial forearm flap donor site. Plast Reconstr Surg 2000;105:698-702.

7. Manders EK, Schenden MJ, Furrey JA, Hetzler PT, Davis TS, Graham WP 3rd. Soft tissue expansion: Concepts and complications. Plast Reconstr Surg 1984;74:493-507.

8. Antonyshyn O, Gruss JS, Mackinnon SE, Zuker R. Complications of soft tissue expansion. Br J Plas Surg 1988;41:239-50.

9. Youm T, Margiotta M, Kasabian A, Karp N. Complications of tissue expansion in a public hospital. Ann Plast Surg 1999;42:396-401. 